
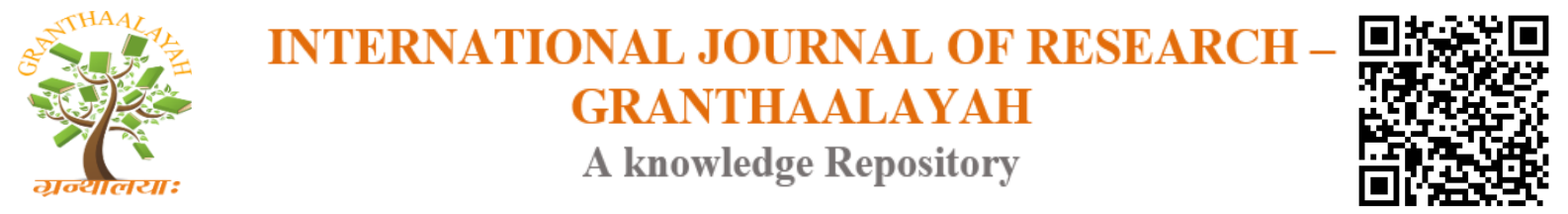

Management

\title{
A CONCEPTUAL STUDY ON EXPERIENTIAL MARKETING: IMPORTANCE, STRATEGIC ISSUES AND ITS IMPACT
}

\author{
Dr. Veto Datta *1 \\ ${ }^{* 1}$ Assistant Professor, Sinhgad Institute of Business Administration and Research, Kondhwa- \\ Saswad Road, Near PMC Octroi center, Kondhwa (bk), Pune-48, India
}

\begin{abstract}
Traditional marketing has been changed with a new approach to marketing called Experiential Marketing. Experiential marketing is also known as "engagement marketing," "event marketing", "participation marketing," or "live marketing". Traditional marketing views consumers as rational decision-makers who care about functional features and benefits. In contrast, experiential marketers view consumers as rational and emotional human beings who are concerned with achieving pleasurable experiences. It is a kind of is a marketing strategy that involves customers directly and inspires them to participate in the development of a brand. This transformation is showing no transformation of slowing down; more and more marketers are moving towards creating experiences for their customers. Therefore experience is an essential element of a today's customer. Experiential Marketing plays an important role in influencing customer behavior and creates a feeling of satisfaction and loyal base .Thus it's a very important concept to study. The research article studies various benefits and strategic issues of experiential marketing, also suggestion are drawn therefrom.
\end{abstract}

Keywords: Experiential Marketing; Impact; Importance; Strategic Issues; Suggestions; Recommendations.

Cite This Article: Dr.Veto Datta. (2017). "A CONCEPTUAL STUDY ON EXPERIENTIAL MARKETING: IMPORTANCE, STRATEGIC ISSUES AND ITS IMPACT." International Journal of Research - Granthaalayah, 5(7), 26-30.

\section{Introduction}

"I have learned that people will forget what you said, people will forget what you did, but people will never forget how you made them feel". -Maya Angelou

Swiftly growing consumer market and their cynical towards advertising give new challenge to marketer to find new methods to capture the attention of their audience. The omnipresence of IT, Power of Brand and ubiquity of communication and entertainment has shifted company approach from "Feature and benefits "towards Experiential Marketing. 
Traditional marketing presents an engineering driven, rational, analytical view of customer, product and competition, now it is considered as untested and outdated model assumptions. It is hardly a psychological based theory about customer, how they view and react to product and competition. In contrast experiential marketing focus on consumer experience .Experience provide sensory, emotional cognitive behavioral and rational value that replace functional value. Experiential Marketing is distinct in four key ways focusing on customer experience, treating consumption as a holistic experience, recognizing both the rational emotional drivers of consumption and using eclectic methodologies

The most vital concept of Experiential Marketing is experience provider (Ex Pro)and Strategic Experience Module (SEM) Sense ,Feel Think, Act, Relate .The Implementation of SEM with the help of Ex Pro must be use to its fullest potential for creating the experience. The concept to Experiential Marketing are sometime too diffused and unlinked so they not only create strategic issues but it also create organizational issues ,issues related to corporate branding ,new products, brand extension, time factor ,cost factor and many more are also affecting. The theory of Experiential Marketing lagging behind practices and ultimately impacting the marketability of business.

Experiential marketing is often seen as working only on external factors - improving the value that customers get. But there has to be similar in consideration for the employee experience. There is very limited work done in India due to lack of creation of rational experiential approach meant for con2sumer in absence of understanding of emotions. Very few organizations are practicing the concept. Experiential marketing is about choosing customers, selling your dreams but here dreams are not a product it is about experience. It allows customer to choose and review the service or product not only based on its features, but according to their preference, interest by experiencing that product or service.

\section{Literature of Review}

Experiential marketing is one marketing concept which has been used widely in different industries in recent years. Liu et al. (2016). Holbrook and Hirschman (1982) introduced experiential sight of consumption as an alternative to the information-processing perspective. According to these authors, Fantasies, Feelings, and Fun (3Fs) are the goals and criteria for successful consumption in the experiential view. In other words, in experiential consumption, the rational and goal-directed customer of the information-processing model turns to a pleasuredirected individual that continuously looks for amusement, enjoyment, and "sensory-emotive" stimulation. Experiential marketing essentially concerned with the six senses: smell, vision, taste, hearing, touch and balance. It has grown in importance because traditional marketing has largely ignored the notion of act experiences. Experiential marketing is not a fad. It is being implemented in practice, yet is not accounted for in the various philosophies (concepts) of marketing. Michelli, (2007) described the five principles for turning ordinary into extraordinary products. One of the principles he described to offer a unique experience to the customers .Further he explained that instead of selling a product with it features it's better to sell their traditional offering if they wrap experience around them. He mentioned that generating a unique customer experience has been as the success key for brands such as Starbucks. Lee et al. (2011) defined experiential marketing as a memorable memory or experience that goes deeply into the 
customer`s mind. According to Kotler (2003), there are two types of marketing: traditional marketing and modern marketing. Modern marketing has overtaken traditional marketing due to the emphasizing on the concepts of customer experience and experiential marketing .Wu, M. Y., \& Tseng, L. H. (2015). Defined that experiential marketing perspective is very broad and help in gaining customer satisfaction and loyalty. Cuellar, et al (2015) have described the companies can take advantage of Experiential Marketing and increase their long term sales and profit.

\section{Objectives of Study}

- To study the benefits of Experiential Marketing.

- To identify the gap between concept of experiential marketing and its implementation.

- To suggest, suggestion and recommendation.

\section{Data and Methodology}

This study is an observatory study based on secondary data. The data has been collected from various journal, books, publications and websites.

\section{Importance of Experiential Marketing}

According to Jack Morton Worldwide survey $75 \%$ of marketer in the US, the UK, Europe, China and Australia affirm they will increase spending on experiential marketing.As per the information by SEM Business Service Ltd in Indian market experiential marketing is holding $15 \%$ of total advertising which is expected to grow by another $10 \%$ in coming years. A survey revealed that the majority of marketers believed "experiential marketing builds customer relationships for the long term". We can use experiential marketing to"

- To Build relationships

- To Raise awareness

- To Increase loyalty

- To Establish relevance

- To Encourage interaction and product trial

- To Create memories

- To Stimulate positive word of mouth

- To Change the mind of dissatisfied customers

- To Create product desire

- To Verify the target audience

- To Increase return on marketing investment

- Stimulate purchase

- Guide preferences

- Develop positive perception

- Show off its attribute 


\section{Strategic Issues in Implementing Experiential Marketing}

Experiential marketing should develop in a different way and give a positive experience on the mind of customer. Experiential marketing knows the brand requirement and understand customer need but problems comes when it is not executed properly. If experiential marketing is not implemented with planning it can create many issues related to:

- Time issue

- Focusing on SEM

- Target right customer group

- High cost involvement issues

- New product issue

- Corporate branding

- Organizational issue

- Brand extension issues

Most companies initially generate impoverished Experiential Marketing strategies they use an approach that is generally diffused and simplified .Some companies are focusing on either one type of experience only or using multiple yet unconnected. Sometime Experiential Marketing requires high cost involvement. Cost involved is too high for an organization to recover in short time. No fixed period is decided for which experiential marketing can be carried out. It requires to be followed for a long period. If not continued, it may not have the desired impact and results will vary on negative side from expected results. A firm with high resource backing may be able to sustain better in competition

\section{Suggestions and Recommendations}

The objective of the company using experiential marketing approach should always towards providing positive experience of product or service to the customer and in return gain loyalty and good will from them. The strategy of experiential marketing should be diverse and multifaceted .Before integrating it with other methods loop points should be checked. Experiential marketing differ from product to product so the strategy should be conceptualized and implemented with definite planning to achieve goals of the company and gain competitive advantage.

To get a better grasp of experiential marketing it should develop in a different way and give a positive experience in the mind of customer. The aim of the approach should diminish the disconnection between what a company says about its offering and what customer actually encounters. The well planned and strong strategy can make a good impact on the buying pattern of customers. The strategy should have ability to do things in a competitive way. This new marketing mix is trying to bring brands to life through experience. Experiential marketing is to stimulate in active manner, to engage consumer in a personal life experience, to allow them to be receptive with the brand in a personalized environment.

\section{Conclusion}

Traditional Marketing already blessed us with valuable set of strategy, different methodology and implementation tools. Now we have entered in new era of information Technology so the 
approach is shifting from Traditional to Experiential Marketing. Experience provide sensory, emotional cognitive behavioral and rational value that replace functional value. Experiential Marketing is powerful instrument it consider consumer as rational and emotional human being who concerned with achieving pleasurable experiences so company need to consider new concept and approaches within the organization, Companies have to recognize the change in Marketing and its implementation to maximize the returns to create and add the value of life. Experiential marketing focus on consumer experience.

\section{References}

[1] Cuellar, S. S., Eyler, R. C., \& Fanti, R. (2015). Experiential Marketing and Long-Term Sales. Journal of Travel \& Tourism Marketing, 32(5), 534-553.

[2] Holbrook (2000) believed that when markets enter into the period of experiential marketing, the major focuses will change from product performance to experiences entertainment

[3] Holbrook, M. B. (2000). The millennial consumer in the texts of our times: Experience and entertainment. Journal of Macro marketing, 20(2), 178-192.

[4] Holbrook, M. B., \& Hirschman, E. C. (1982). The experiential aspects of consumption: Consumer fantasies, feelings, and fun. Journal of consumer research, 132-140.

[5] Kotler, P. (2003). Marketing Insights from A to Z: 80 Concepts Every Manager Needs to Know. John Wiley \& Sons, Inc.

[6] Lee, M. S., Hsiao, H. D., \& Yang, M. F. (2011). The study of the relationship among experiential marketing, service quality, customer satisfaction and customer loyalty. The International Journal of Organizational Innovation, 3(2), 353-379.

[7] Liu, A. C., Chou, T. Y., \& Chen, S. H. (2016). The Effects of Experiential Marketing on Customer Revisit Behaviors: An Empirical Study of Hot spring Industry. Transylvanian Review, 24(6).

[8] Michelli, J. (2007), the Starbucks Experience: 5 Principles for Turning Ordinary Into Extraordinary. New York: McGraw Hill

[9] Wu, M. Y., \& Tseng, L. H. (2015). Customer satisfaction and loyalty in an online shop: an experiential marketing perspective. International Journal of Business and Management, 10(1), 104.

*Corresponding author.

E-mail address: taragem3@gmail.com 